\title{
PENGUJIAN UNDANG - UNDANG NO. 12 TAHUN 1995 TENTANG PEMASYARAKATAN TERHADAP UUD-45 DI MAHKAMAH KONSTITUSI DALAM KONTEKS PENEGAKAN HUKUM
}

Oleh :

Nunuk Sulisrudatin, SH., SosPol., MSi.

\begin{abstract}
Abstrak:
Pemasyarakatan pada dasarnya adalah kegiatan untuk melakukan pembinaan Warga Binaan Pemasyarakatan (Narapidana, Anak Didik Pemasyarakatan dan Klien pemasyarakatan) berdasarkan sistem, kelembagaan, dan cara pembinaan yang merupakan bagian akhir dari pemidanaan dalam Tata Peradilan Pidana di Indonesia. Undang- undang No 12 tahun 1995 tentang Pemasyarakatan telah menegaskan bahwa "Sistem Pemasyarakatan" adalah suatu tatanan mengenai arah dan batas, serta cara pembinaan Warga Binaan Pemasyarakatan berdasarkan Pancasila yang dilaksanakan secara terpadu antara Pembina, Yang dibina, dan Masyarakat untuk meningkatkan kualitas Warga Binaan Pemasyarakatan agar menyadari kesalahan, memperbaiki diri, dan tidak mengulangi tindak pidana, sehingga ia kemudian dapat diterima kembali oleh lingkungan masyarakat, dapat aktif berperan dalam pembangunan, dan dapat hidup secara wajar sebagai warga yang baik dan bertanggung jawab.
\end{abstract}

\section{PENDAHULUAN}

Adanya pengajuan permohonan pengujian Undang- undang nomor 12 tahun 1995 tentang Pemasyarakatan terhadap Undang- undang Dasar 1945, yang mempermasalahkan Dasar Hukum Remisi (Pengurangan masa pidana)adalah merupakan sebuah pemikiran kritis yang perlu mendapat perhatian baik dari kalangan praktisi maupun dari kalangan ilmuwan. Hal ini diajukan oleh sebuah Asosiasi Advokad Konstitusi (AAK) yang berkedudukan di Palembang.
Pemasyarakatan pada dasarnya adalah kegiatan untuk melakukan pembinaan Warga Binaan Pemasyarakatan (Narapidana, Anak Didik Pemasyarakatan dan Klien pemasyarakatan) berdasarkan sistem, kelembagaan, dan cara pembinaan yang merupakan bagian akhir dari pemidanaan dalam Tata Peradilan Pidana di Indonesia.

Undang - undang No. 12 tahun 1995 tentang Pemasyarakatan telah menegaskan bahwa "Sistem Pemasyarakatan" adalah suatu tatanan mengenai arah dan batas, serta cara pembinaan Warga Binaan Pemasyarakatan berdasarkan Pancasila 
yang dilaksanakan secara terpadu antara Pembina, Yang dibina, dan Masyarakat untuk meningkatkan kualitas Warga Binaan Pemasyarakatan agar menyadari kesalahan, memperbaiki diri, dan tidak mengulangi tindak pidana, sehingga ia kemudian dapat diterima kembali oleh lingkungan masyarakat, dapat aktif berperan dalam pembangunan, dan dapat hidup secara wajar sebagai warga yang baik dan bertanggung jawab.

Menurut Prinsip - prinsip untuk perlindungan semua orang yang berada dibawah bentuk apapun atau pemenjaraan (Body of Principles for the Protection of All Persons Under Any Form of Detention or Imprisonment) yang dikeluarkan oleh Majelis Umum PBB pada tanggal 9 Desember 1988 dengan Resolusi 43 /173, bahwa tidak boleh ada pembatasan atau pelanggaran terhadap setiap hak- hak asasi manusia dari orang- orang yang berada dibawah bentuk penahanan atau pemenjaraan. Penangkapan, penahanan atau pemenjaraan harus diperlakukan dalam cara yang manusiawi dan dengan menghormati martabat pribadi manusia yang melekat.

Bab II UU No. 12 tahun 1995 tentang Pemasyarakatan mengatur tentang Hak dan Kewajiban Narapidana dan Anak Didik Pemasyarakatan. Selanjutnya Bab II, bagian ke Sembilan pasal 34, mengatur hal- hal yang berkaitan dengan Remisi / Pengurangan Masa Pidana.

(1). Setiap Narapidana dan Anak Pidana yang selama menjalani masa pidana berkelakuan baik berhak mendapatkan Remisi;

(2). Remisi sebagaimana dimaksud dalam ayat (1) dapat ditambah, apabila selama menjalani pidana, yang bersangkutan :
- Berbuat jasa kepada Negara;

- Melakukan perbuatan yang bermanfaat bagi Negara atau kemanusiaan;

- Melakukan perbuatan yang membantu kegiatan Lembaga Pemasyarakatan.

(3). Ketentuan untuk mendapatkan Remisi sebagaimana dimaksud dalam ayat (1) dan ayat (2) berlaku juga bagi Narapidana dan Anak Pidana yang menunggu grasi sambil menjani pidana.

Pada dasarnya Remisi dalam arti pengurangan masa pidana telah diberikan kepada Narapidana yang telah memenuhi persyaratan tertentu, dan ini diberikan setiap tanggal 17 Agustus tiap tahunnya dalam rangka peringatan Hari Kemerdekaan Indonesia. Selanjutnya logika pemberian Remisi pada masamasa sekarang adalah selain memberikan "Semangat berkelakuan baik" bagi Narapidana, dan dalam rangka menunjang Keamanan dan ketertiban dalam Lembaga Pemasyarakatan, ternyata Remisi juga merupakan salah satu teknis pembinaan Narapidana dalam rangka mengurangi "Kondisi Over Kapasitas" dan mengurangi beban anggaran belanja Negara.

\section{PEMBERIAN REMISI DALAM KONTEKS HAM DAN GUGATAN AAK}

Memperhatikan sejarah masa lalu serta kronologis dan filosofis tentang Pemasyarkatan pada dasarnya kita harus melihat kembali mengenai gagasan Sistem Pemasyarakatan yang diawali dari sistem Penjara menuju pada sistem Pemasyarakatan. Hal ini dapat dilihat 
pada saat masuk abad ke XIX setelah perang Dunia ke II.

Penjara adalah merupakan tempat terhukum yang karena perbuatannya melakukan tindak pidana, oleh pengadilan diputus dan telah memperoleh kekuatan hukum tetap untuk menjalani hukumannya. Ditempat ini orang yang bersalah tadi diperlakukan sedemikian rupa dengan mempergunakan sistem perlakuan tertentu berupa penyiksaan dan hukuman badan lainnya, dengan harapan agar siterhukum betul- betul merasa bertobat dan jera sehingga kemudian dia tidak akan melakukan lagi perbuatanperbuatan yang menyebabkan ia masuk penjara.

Pidana Penjara atau pidana lain yang menghilangkan kemerdekaan begerak seseorang, pada akhirnya bertujuan "Melindungi Masyarakat dari segala bentuk Kejahatan", selanjutnya dikenal dengan "Politik Kriminal Pemerintah" adalah suatu upaya melindungi masyarakat dari segala bentuk kejahatan. Sejalan dengan perjalanan waktu ternyata konsepsi sistem Kepenjaraan yang membuat orang jera dengan perlakuan yang tidak manusiawi tidak berhasil, mengingat "Jera bukan merupakan jalan untuk narapidana menjadi Tobat".

Hal- hal lainnya yang membuat sistem Penjeraan menjadi tidak efektif antara lain:

1. Tidak ada pentahapan dalam proses pemenjaraan;

2. Sistem perlakuan yang diberikan kepada narapidana sifatnya hanya untuk mengisi waktu;

3. Label dan apriori dari masyarakat tidak mendukung keberhasilan pembinaan narapidana;
4. Kurang memperhatikan partisipasi dari masyarakat dan lingkungan; ${ }^{1}$

Dengan demikian usaha- usaha untuk perbaikan dan penambahan terhadap kekurangan yang ada dalam sistem Kepenjaraan terus dilakukan, sehingga pada akhirnya sampai pada usaha untuk mengganti sistem yang ada menjadi sistem yang lebih baik yaitu "Sistem Pemasyarakatan" yang juga merupakan tujuan dari pidana. Dalam hal ini pelaksanaan pembinaan dilakukan secara lebih manusiawi, dimana narapidana tersebut hanya dibatasi masalah "Kemerdekaan Bergeraknya saja", selain itu dari sisi Hak Asasi Manusianya mereka lebih diperhatikan.

Secara singkat perlu diuraikan bahwa usaha pergantian dari sistem Kepenjaraan menjadi sistem Pemasyarakatan, ini didasarkan atas pertimbangan bahwa Sistem Kepenjaraan sudah tidak sesuai lagi dengan kepribadian bangsa Indonesia yang dalam kehidupan sehari- hari selalu berpedoman dan berlandaskan pada falsafah Pancasila. Pemasyarakatan yang kita kenal sekarang adalah merupakan suatu proses pembinaan narapidana yang didasarkan pada Pancasila sebagai falsafah bangsa Indonesia, dan memandang narapidana sebagai makhluk Tuhan secara individu dan juga sebagai anggota masyarakat.

Sejak tahun 1945 setelah perang Dunia II, perlakuan terhadap narapidana mendapat perhatian khusus dari kalangan dunia Internasional. Karena dalam perlakuan tersebut berlandaskan pada Perikemanusiaan, hingga tercipta "Standard Minimum Rules for the Treatment of Prisoners". Yang dalam

${ }^{1}$ Widiada Gunakaya S.A.SH; Sejarah dan Konsepsi Pemasyarakatan;Armico Bandung; 1988; 41. 
Bagian I Peraturan- peraturan Penerapan Umum / Prinsip Dasar menyiratkan tentang Hak asasi Manusia Yang "Berlaku Universal" (Peraturan- peraturan berikut harus diterapkan secara adil, tidak boleh ada diskriminasi berdasarkan alasanalasan Ras, warna kulit, jenis kelamin, bahasa, agama, pendapat politik, atau pendapat lain, asal- usul kebangsaan atau sosial, harta kekayaan, kelahiran atau status lain). ${ }^{2}$

Selanjutnya berkembang teori- teori baru dalam sistem Pembinaan narapidana seperti teori Rehabilitation, Sicial Reintegration, dan Resosialitation yang menggantikan teori lama yaitu Retributive Punishment, Incapasitation. Dengan dasar membela dan mempertahankan "HAk Asasi Manusia", pada suatu Negara Hukum, sipelanggar hukum harus juga mendapat perlindungan hukum. Maka oleh Sahardjo, SH. pada tanggal 5 Juli 1963 telah dikemukakan suatu gagasan "Sistem Pemasyarakatan" sebagai tujuan dari pidana Penjara, yang diucapkan pada pidatonya yang berjudul "Pohon Beringin Pengayoman" pada penganugerahan gelar Doctor Honoris Causa dalam Ilmu Hukum di Universitas Indonesia.

Dengan begitu kemudian konsepsi tentang hukum nasional digambarkan dengan sebuah pohon beringin yang melambangkan Pengayoman untuk dijadikan lambang oleh Departemen Kehakiman dengan harapan agar menjadi penyuluh bagi petugasnya terutama dalam menjalankan hukum, Peradilan, dan memberikan keadilan dalam memperlakukan para pelanggar hukum. Dari pengayoman ini nyata bahwa

${ }^{2}$ UU No. 12 / 1995 tentang Pemasyarakatan beserta Peraturan Pelaksanaannya, dilengkapi Peraturan dan Prinsip Penahanan dan Pemenjaraan PBB; Hadisetiadi Tunggal SH; Harvarindo 2000; 200. menjatuhi pidana bukanlah tindakan balas dendam dari Negara. Negara dalam hal ini telah mengambil kemerdekaan seseorang, dan pada waktunya akan mengembalikan orang itu kemasyarakat lagi. Untuk itu Negara mempunyai kewajiban terhadap seorang narapidana untuk membuat mereka "Tidak menjadi lebih jahat dari sebelumnya".

Pada dasarnya konsepsi Pemasyarakatan bukan semata- mata merumuskan tujuan dari pidana penjara, melainkan merupakan suatu sistem pembinaan, dengan suatu metodologi dibidang "Treatment of Offenders" yang multilateral oriented dengan pendekatan yang berpusat kepada potensi- potensi yang ada pada diri individu yang bersangkutan, maupun yang ada ditengah- tengah masyarakat sebagai suatu keseluruhan (Community Base Treatment).

Dengan demikian secara konsepsional antara Sistem Pemasyarakatan dan Sistem Kepenjaraan sangat berbeda. Hal ini dapat dilihat dari penerapan sistem yang berdasarkan Rehabilitasi dengan fokus perlakuannya yang secara eksklusif dipusatkan kepada individu yang bersangkutan, mengingat dalam sistem Kepenjaraan yang lebih ditonjolkan adalah "Tujuan Perlakuannya yaitu Penjeraan atau Deterence".

Setelah berkembang doktrin Penjeraan, selanjutnya berkembang doktri- doktrin lain seperti Rehabilitasi, Resosialisasi, Reformasi yang pada hakekatnya mencela doktrin Deterence. Dalam dunia Penologi aliran aliran yang menganut "Punitive Imprisonment" digolongkan kedalam "Classical Penology", sedangkan yang menganut "Rehabilitative Imprisonment" di masukkan kedalam golongan New- 
Penology ${ }^{3}$, dan golongan ini berkembang terus dengan penerapan Approach yang lebih memperhatikan pada kekuatankekuatan yang ada ditengah- tengah masyarakat. Sehubungan dengan hal tersebut diatas pelaksanaan Sistem Pemasyarakatan dengan cara pendekatan yang mengarah pada kekuatan dalam masyarakat, dengan begitu narapidana yang menjadi unsur yang menjalani pembinaan,dan petugas Lembaga Pemasyarakat selaku unsur Pembinanya, dalam hal ini ketiga unsur tersebut harus saling berkaitan untuk menunjang proses pembinaan narapidana.

"Remisi Untuk Narapidana", dalam hal ini Remisi merupakan bagian dari proses pembinaan narapidana yang teknis pengaturannya sebagaimana dituangkan dalam UU No. 12 tahun 1995 tentang Pemasyarakatan khususnya pada pasal 34 dan pasal 35. Secara teknis proses ini sudah berada diluar koridor Kekuasaan Kehakiman, mengingat butir Konsepsi Pemasyarakatan yang menyebutkan bahwa :"Negara mempunyai kewajiban terhadap seorang narapidana untuk membuat mereka tidak menjadi lebih jahat dari sebelumnya".

Memperhatikan proses persidangan "Gugatan dari AAK" dimana pada sidang Panel (Proses Pemeriksaan Pendahuluan) semata- mata untuk memberikan kesempatan pada pemohon untuk memenuhi persyaratan pengajuan gugatan. Dalam hal ini keabsahan Legal Standing dan persyaratan material lainnya harus dipenuhi. Sebagaimana yang dikemukakan oleh Pemohon bahwa : "Perbaikan pada kedudukan Legal Standing menurut Pemohon telah mencukupi atas dasar Undang - undang No. 12 tahun 1995 tentang

3 Ibid. hal 84
Pemasyarakatan khususnya pada pasal 14 ayat (1) butir i "Narapidana berhak mendapatkan Pengurangan Masa Pidana", dan pasal 14 ayat (2) :"Ketentuan mengenai syarat- syarat dan tatacara pelaksanaan hak- hak Narapidana sebagaimana dimaksud dalam ayat (1) diatur lebih lanjut dengan Peraturan Pemerintah", yang bertentangan dengan Undang- undang Dasar Negara Republik Indonesia - 1945.

Pemohon (AAK) dalam hal ini memberikan argument bahwa :" Pada dasarnya AAK memiliki visi untuk merealisasikan cita- cita konstitusional RI sesuai dengan UUD- 45, dan merealisasikan penegakan hukum dan hak asasi manusia secara integral dalam arti seluas - luasnya, serta memiliki misi meningkatkan pengetahuan dan pemahaman masyarakat hukum dan HAM". Bahwa menurut AAK pasal 14 ayat (1) butir i dan ayat (2) UU No. 12 / 1995 tentang Pemasyarakatan dalam hal ini telah memberi wewenang kepada Presiden sebagai pemegang Kekuasaan Pemerintah Negara (Eksekutif) untuk melakukan intervensi terhadap kekuasaan Kehakiman yang Merdeka untuk menyelenggarakan peradilan guna menegakkan hukum dan keadilan.

\section{BEBERAPA PENDAPAT PAKAR DALAM RANGKA "GUGATAN REMISI"}

Berkaitan dengan adanya gugatan dari Asosiasi Advokad Konstitusi (AAK) yang berkedudukan di Palembang yang mengajukan permohonan Pengujian Undang- undang No. 12 tahun 1995 tentang Pemasyarakatan sebagai Dasar hukum Remisi bagi Narapidana terhadap Undang- undang Dasar 1945. Dalam gugatan AAK tersebut secara umum 
menyatakan bahwa pada kenyataannya Undang- undang No. 12 tahun 1995 tentang Pemasyarakatan bertentangan dengan UUD- 1945, khususnya pada pasal 14 ayat (1) butir I dan pasal 14 ayat (2). Untuk itu dikemukakan beberapa pendapat pakar yang turut serta mengikuti proses jalannya sidang Pengujian tersebut di Mahakamah Konstitusi Jakarta ${ }^{4}$ :

\section{A. Prof. Andi Hamzah}

1. Bila ditinjau dari aspek yuridis yang menyangkut hukum pidana dan hukum acara pidana, maka cara berfikir (pemohon / penggugat) adalah keliru bahkan terlalu picik;

2. Bahwa menurut pemohon / penggugat ternyata "Pemberian Remisi itu campur tangan pemerintah Eksekutif terhadap kekuasaan Kehakiman karena telah mempunyai kekuatan hukum tetap, akan tetapi dijalankan tidak seperti dengan yang telah diputuskan" ;

3. Pernyataan tersebut terdapat Kekeliruan Yuridis sebagai berikut:

a. Bahwa hukum Acara Pidana yang mengatur tentang Kekuasaan Kehakiman dimulai dari Penyidikan dan berakhir pada Putusan menjadi tetap. Jadi setelah keputusan menjadi tetap, tidak ada urusan lagi dengan Kekuasaan Kehakiman. Hal ini juga diajukan oleh Sarjana Amerika Joan Miller, bahwa hukum acara pidana berakhir pada saat dijatuhkannya putusan oleh Pengadilan.

\footnotetext{
${ }^{4}$ Warta Pemasyarakatan No. 20 tahun VIIJanuari 2006; 17.
}

b. Seperti apa yang dikatakan oleh Pemohon bahwa pasal 14 ayat 2 huruf I Undang- undang Pemasyarakatan, yaitu "Narapidana berhak mendapatkan pengurangan hukuman / Remisi" bertentangan dengan UUD- 45 dan pasal 24 ayat 1 tentang Kekuasaan Kehakiman yang sebenarnya telah berakhir pada putusan itu menjadi tetap, maka konsekuensi pemikiran demikian berarti bahwa pemberian Grasi, Amnesti, dan Abolisi oleh Presiden juga "Mencampuri urusan Kehakiman / Yudikatif "? Akibat lebih jauh lagi akan mengacaukan seluruh sistem Hukum Pidana kita. Dengan demikian pula bahwa KUHP juga bertentangan dengan UUD- 45 karena didalam KUHP ada "Pelepasan Bersyarat", bahwa seseorang bisa mendapatkan Pelepasan Bersyarat jika telah menjalankan 2/3 dari masa pidananya, jadi jika seseorang dihukum 15 tahun maka dia hanya menjalankan 10 tahun sudah keluar, jika mereka berkelakuan baik / tidak melanggar apapun.. Jadi apabila mau "Menggugat Remisi", selayaknya juga harus menggugat KUHP yang berlaku diseluruh dunia. Jadi kalau mau merubah Undangundang ini ( UU- tentang Pemasyarakatan) harus pula merubah KUHP.

c. Konstitusi Belanda juga menganut Lembaga Pelepasan Bersyarat dan Remisi, dengan 
demikian bertentangan dengan Sejarah Hukum dan Perbandingan Hukum. Sejak Zaman Hindia Belanda sudah ada Remisi, yaitu dalam rangka memperingati Ulang Tahun Ratu Belanda Welhelmina tiap tanggal 31 Agustus. Hal ini bertentangan dengan sejarah hukum karena sejak Indonesia memiliki KUHP, pengadilan zaman Hindia Belanda sudah ada Pelepasan Bersyarat. Demikian halnya dengan Perbandingan Hukum, Remisi itu ada dimana- mana, juga di Belanda.

Ditinjau dari sudut substansi Peraturan dalam Petitum (Gugatan Pemohon) ini, tidak dapat dibuktikan oleh Pemohon bahwa "Terdapat Adanya Kerugian" yang diderita oleh Pemohon akibat dari peraturan perundang- undangan yang mengatur tentang Remisi. Selain itu pernyataan "Kerugian Yang Diderita" harus ada hubungan kausal;

Alasan- alasan yang oportunistik (sesuai dengan keadaan) yaitu "Penjara akan penuh", bertentangan dengan sistem Pemasyarakatan . Intinya, tidak mencampuri urusan kehakiman karena sudah lewat hukum acaranya. Bahwa "Pembinaan Narapidana" adalah menjadi kewenangan eksekutif, Cq Direktorat Jenderal Pemasyarakatan, berarti bukan urusan pengadilan lagi;

Seorang yang sudah menjadi Narapidana karena Ia telah mempunyai kekuatan hukum tetap dalam proses peradilannya, pada dasarnya Ia tidak mempunyai hubungan lagi dengan urusan
Kehakiman, selanjutnya Ia sudah menjadi urusan eksekutif, dan pemberian Remisi sama sekali tidak merubah "Putusan Hakim". Bila tercatat 5 (IIma) tahun dalam vonis Pengadilan, maka akan tetap tercatat 5 tahun. Untuk hal ini dapat dicontohkan sebagai berikut, bahwa seperti narapidana yang dihukum penjara 5 (lima) tahun, maka isterinya berhak untuk meminta cerai, walaupun dalam pelaksanaannya ia menjalani tidak sampai 5 tahun, karena dalam menjalani proses pembinaan di Lembaga Pemasyarakatan Ia mendapatkan pemotongan masapidana dengan Remisi. Gugatan isteri tersebut tetap saja syah karena putusan hakim 5 (lima) tahun, ini adalah bukti bahwa eksekutif "Tidak Mengubah" atau mengganggu putusan hakim.

\section{B. Komarudin (DIrektur Litigasi Departemen Hukum dan HAM)}

1. Dari sisi kedudukan Hukum Pemohon / Penggugat (AAK), mereka tidak mempunyai kualifikasi sebagai pihak yang berhak mengajukan permohonan uji undang- undang No. 12 tahun 1995 terhadap UUD- 45. karena Pihak yang mempunyai kewenangan untuk mengajukan uji Undang- undang adalah :

\section{a. Perorangan Warga Negara Indonesia;}

b. Kesatuan masyarakat hukum Adat sepanjang masih hidup dan sesuai dengan perkembangan masyarakat dan prinsip Negara Kesatuan Republik Indonesia yang diatur dalam undang- undang; 
c. Badan Hukum Publik atau
privat;

d. Lembaga Negara.

2. Bila sampai terjadi ada undangundang yang meniadakan Remisi, yang sudah melekat dan menyatu dalam proses pembinaan orang yang dipidana selama ini, maka kemungkinan dapat terjadi bahwa Narapidana justru punya hak untuk mengajukan gugatan terhadap undang- undang yang bersangkutan, karena secara spesifik haknya dirugikan;

3. Harus ada hubungan sebab akibat antara "Kerugian" akibat diberlakukannya undang- undang yang berkaitan dengan Remisi. Kerugian itu secara fakta tidak dinyatakan walaupun secara sederhana oleh pemohon. Seperti diketahui bahwa kerugian yang ditimbulkan akibat adanya undang- undang yang akan diuji itu harus mempunyai hubungan sebab akibat.

4. Dengan dikabulkannya pemohon, maka kerugian konstitusional yang didalilkan tidak terjadi lagi;

5. Legal Standing dari Pemohon, kerugian apa yang diderita dan akan dirugikan dengan berlakunya undang- undang yang berkaitan dengan Remisi, bahwa dengan adanya Permohonan dari Pemohon maka Mahkamah Konstitusi dapat memutuskan halhal sebagai berikut :

a. Ditolak, keseluruhan dari kedudukan Legal Standing, dalam arti kedudukan hukum sudah tidak mengena;

b. Tidak diteriman, Legal Standing tidak diterima, mengingat semua kerugian tidak muncul, atau beberapa bagian dikabulkan.

6. Kita bisa meyakinkan hakim konstitusi bahwa Remisi ternyata sudah berlaku sejak ratusan tahun dan tidak bertentangan dengan undang- undang, selanjutnya meyakinkan Hakim agar Legal Standing pihak penggugat tidak diterima.

\section{Mualimin (Kasubdit Litigasi - Dit Litigasi Departemen Hukum dan HAM)}

1. Pada Direktorat Litigasi DitJen Peraturan Perundang- undangan, ada sekitar 76 Undang- undang yang dimohonkan untuk diuji di Mahkamah Konstitusi;

2. Pada dasarnya kerugian- kerugian konstutusional terhadap pemohon selayaknya harus memenuhi kualifikasi tertentu. Dalam pengalaman selama kurang lebih dua tahun, apabila persidangan ternyata sudah melewati persidangan panel (di Mahkamah Konstitusi itu ada sidang pleno dan sidang panel, apabila panel dipengadilan TUN merupakan semacam Discustion Process), pada saat itulah hakim menanyakan kualifikasi pemohon;

3. Direktorat Litigasi berkesimpulan, apabila permohonan sudah disampaikan kepada pemerintah, secara patut dan layak, akhirnya kualifikasi pemohon (legal standing) akan lolos, walaupun nantinya pada putusan Mahkamah Konstitusi akan dipertimbangkan lebih lanjut. 
4. Direktorat Litigasi Peraturan Perundang- undangan dalam memperhatikan Legal Standing selanjutnya akan mempertanyakan masalah pembuktian,

a. Apakah sudah memenuhi syarat atau belum, jadi dalam hal ini apabila gugatan pemohon sudah sampai di Mahkamah Konstitusi pada sidang Panel, permasalahan Legal Standing pada dasarnya sudah diangap telah memenuhi syarat,

b. Bahwa ada hal menarik pada Mahkamah Konstitusi bila ditinjau dari UU No. 24 tahun 2003 tentang Mahkamah Konstitusi, pasal 60 yang menyebutkan bahwa :" Terhadap materi muatan ayat, pasal, dan / atau bagian dalam undang- undang yang telah diuji, tidak dapat dimohonkan pengujian kembali". Hal ini dimaksudkan bahwa yang sudah dimohonkan untuk diuji berarti termasuk dalam kategori "Azas Nebis In Idem". akan tapi Mahkamah Konstitusi mengeluarkan peraturan No. 06 tahun 2004 yang menyebutkan bahwa :"Ada yang disebut sebagai Conditionally Constitutional". Apabila konstitusional ini tetap ditanggapi, maka dikhawatirkan bahwa suatu ketika mungkin saja Undang- Undang No. 12 tahun 1995 tentang Pemasyarakatan akan terus menerus digugat seperti halnya dengan undang- undang kepailitan, undang- undang Pers, asalkan dari pihak yang menggugat dapat menyampaikan nalarnya secara logika, dan mereka bisa mengajukan pembuktian adanya kerugian konstitusional yang lain selain yang terdahulu.

7. Perlu dirumuskan substansi atau hal - hal yang berkaitan dengan argument pemerintah. Argumentasi substansi, sejarahnya Remisi, pengaturan tentang Remisi, akibat Remisi kalau dicabut dan seterusnya.

\section{PENUTUP}

Memperhatikan penjelasan Saksi Ahli dalam persidangan gugatan pihak AAK kepada Pemerintah $\mathrm{Cq}$ Direktorat Jenderal Pemasyarakatan menyatakan bahwa :"Ruang lingkup Acara Pidana dengan merujuk pendapat dari J.M Van Bemmellen mencakup ada 7 (tujuh) tahapan yaitu :

1. Mencari kebenaran;

2. Mencari Pembuat Tindak Pidana;

3. Menangkap Pembuat kejahatan dan bila perlu menahannya;

4. Mengumpulkan bahan- bahan bukti untuk diajukan pada sidang pengadilan;

5. Pengambilan putusan Hakim;

6. Upaya Hukum untuk melawan putusan Hakim;

7. Pelaksanaan putusan Hakim".

Untuk memperjelas pernyataan tersebut diatas, maka sejak orang telah mempunyai kekuatan hukum tetap untuk mejalani pidananya dengan dilaksanakan eksekusi oleh pihak Kejaksaan, maka dalam hal ini proses yang berada pada koridor kekuasaan Kehakiman (Lingkup Criminal Justisce Sytsem) telah berakhir, selanjutnya narapidana berada pada kekuasaan dan tanggung jawab Negara 
dalam hal ini dilaksanakan oleh Direktorat Jenderal Pemasyarakatan.

Dalam implementasi Rencana Aksi Nasional Hak Asasi Manusia (Kepres No 40 tahun 2004 ) dalam Pilar ke V "Penerapan Norma dan Standar Instrumen Hak Asasi Manusia" pada tujuan dan sasaran yang ke 6 (enam) berkaitan dengan "Perlindungan Hak Kelompok Rentan Lainnya, salah satunya adalah "Peningkatan Upaya Perlindungan Hak Tahanan dan Narapidana"s.

Pada dasarnya Pemberian Remisi bagi Narapidana sesuai dengan yang diatur dalam UU No. 12 tahun 1995 tentang Pemasyarakatan adalah merupakan hak Narapidana sebagaimana didukung melalui RANHAM 2004 - 2009, dan hal ini perlu mendapat perhatian khusus.

Sesuai dengan amanat pembukaan Undang- undang Dasar 1945, undangundang No. 39 tahun 1999 tentang HAk Asasi Manusia (HAM) dan Keputusan Presiden RI. No. 40 tahun 2004 tentang Rencana Aksi Nasional Hak Asasi Manusia (RAN-HAM) 2004 - 2009, menyatakan bahwa pemerintah merupakan penanggung jawab utama dalam upaya perlindungan, penegakan, pemajuan dan pemenuhan HAM bagi semua warga Negara, dan untuk menjalankan tanggung jawab tersebut, selayaknya pemberian Remisi bagi Narapidana tidak dijadikan permasalahan umum.

\footnotetext{
${ }^{5}$ KepPres No 40 tahun 2004 Tentang RANHAM tahun 2004 - 2009 Pilar ke V
}

\section{DAFTAR PUSTAKA}

1. Edwin H. Sutherland, Principles Of Criminology, Sixth Edition,J.B. Lippincott Company, Copyright 1960

2. A. Widiada Gunakaya S.A.SH, Sejarah Dan Konsepsi Pemasyarakatan, Armico; Bandung; 1988.

3. Dr.SOedjono DIrdjosisworo, Sejarah dan Asas - asas Penologi (Pemasyarakatan Armoco, Bandung, 1984).

4. Drs.A. Sanusi Has, Dasar- dasar Penologi; Rasanta, Jakarta; 1994.

5. Harkristuti Harkrisnowo, SH. Christianus H. Panjaitan, Pedoman mengenai Standar - standar Internasional yang berhubungan dengan Penahanan Pra-Sidang, Professional Training Series No. 3 .

6. R.Achmad S. Soema diPradja SH, Romli Atmasasmita SH. Sistem Pemasyarakatan di Indonesia, BPHN; 1979.

7. Undang- Undang Dasar RI 1945, (Setelah amandemen Kedua tahun 2000);

8. Undang- Undang RI No. 24 tahun 2003 Tentang Mahkamah Konstitusi.

9. Undang- undang No. 12 tahun 1995 Tentang Pemasyarakatan; Harvarindo; 2000.

10. KepPres No 40 tahun 2004 tentang Rencana Aksi Nasional HAk Asasi Manusia

11. Warta Pemasyarakatan No $20 / 21$ tahun VII - 2006.

12. Sumber Koran : Kompas 10 Februari 2006. 